\title{
LISTY AUGUSTA CIESZKOWSKIEGO JUNIORA DO MARIANA ZDZIECHOWSKIEGO Z LAT 1907-1913
}

\author{
PRZYGOTOWAŁA DO DRUKU MONIKA MARLĘGA
}

Listy Augusta Cieszkowskiego juniora do Mariana Zdziechowskiego są świadectwem bliskiej znajomości, jaka łączyła profesora i syna sławnego polskiego filozofa. August Adolf Józef Cieszkowski (1861-1932) był agronomem i filantropem, propagatorem myśli swojego ojca, Augusta Cieszkowskiego (1814-1894), przedstawiciela filozofii narodowej, polityka i ekonomisty.

Augusta Adolfa Józefa Cieszkowskiego w roku 1896 spotkał Marian Zdziechowski w Jasnej Polanie podczas odwiedzin u Lwa Tołstoja. Syn zafascynowany do głębi ideami swojego ojca, poświęcił całe swe życie na ich upowszechnienie ${ }^{1}$. Młody Cieszkowski, jako spadkobierca spuścizny ojca, pierwszy przetłumaczył z języka niemieckiego takie dzieła jak Prologomena do historiozofii ${ }^{2}$, Bóg $i$ Palingeneza. Część pierwsza - krytyczna ${ }^{3}$, Ojcze nasz. Syn okazał się starannym thumaczem. Jego przekłady, jak na swój czas, były wzorcowe, dokonane z wielkim pietyzmem i kompetencją. O młodym Cieszkowskim pisał Zdziechowski w liście do Piotra Siergiejenki ,Jest to człowiek zbyt zachodni, aby mógł rozumieć Tołstoja" ". Nie ulega jednak wątpliwości,

\footnotetext{
Bazyli Białokozowicz, Marian Zdziechowski i Lew Totstoj, Białystok 1995, s. 282

2 August Cieszkowski, Prolegomena do historiozofii, przeł. August Cieszowski syn, Poznań 1908 (tytuł oryginału: Prolegomena zur Historiosophie, Berlin 1938).

3 Bóg i palingenezya. Część pierwsza - krytyczna, przeł. August Cieszowski syn, Poznań 1912 (tytuł oryginału: Gott und Palingenesie. Erster, krytischer Theil, Berlin 1942).

4 List Mariana Zdziechowskiego do Piotra Siergiejenki z 1 VI 1908, cyt za: Bazyli Białokozowicz, dz. cyt., s. 166.
} 
że wielkopolskiego dyletanta cenił, skoro w pewnym momencie zaproponował mu objęcie redakcji „Świata Słowiańskiego”.

Jako badacz towianizmu Zdziechowski chciał dowiedzieć się, czy istniała jakakolwiek zbieżność myśli między przywódcą towiańczyków a filozofem słowiańskim. Interesował go stosunek zarówno Zygmunta Krasińskiego, jak też samego Cieszkowskiego ojca, do poglądów mesjanistycznych przywódcy Koła Sprawy Bożej. Tym bardziej, że Krasiński traktował autora Ojcze nasz jako swego nauczyciela, przyjaciela i powiernika.

Listy Cieszkowskiego syna do Mariana Zdziechowskiego ukazują dwie postawy wobec spuścizny romantycznej, w tym przywoływanej tu przede wszystkim twórczości Cieszkowskiego ojca i autora Przedświtu. Syn filozofa jest pewny, że ojciec nie interesował się w sposób dogłębny poglądami Towiańskiego. Postawa Zdziechowskiego jest postawą badacza, który zawsze dąży do rozwikłania postawionych przed sobą problemów. Nie posiadamy listów Zdziechowskiego do Cieszkowskiego syna, ale z korespondencji, którą dysponujemy, jasno wynika, że profesor, który wcześniej dokładnie badał twórczość i dorobek Krasińskiego, był ciekawy, czy występowała jakakolwiek formalna styczność między filozofią Cieszkowskiego a towianizmem. Zanim Krasiński radykalnie zmienił swój stosunek do towianizmu, dokonywał prób „przerzucania mostów” między filozofią przyjaciela a ideami towiańczyków. W 1843 roku Krasiński zarzucił Cieszkowskiemu, że „za mało dba o ruch paryski” oraz przekonywał go, że ,podstawa ich [towiańczyków] prawdą jest"5. Poza tym zabiegał zwłaszcza o silniejsze zaakcentowanie w historiozofii Cieszkowskiego wątków mesjanistycznych i eschatologicznych. Informacje udzielone Zdziechowskiemu przez Cieszkowskiego syna miały służyć w sprecyzowaniu i oszlifowaniu ostatecznych wniosków zamieszczonych w pracy Wizja Krasińskiego.

Zygmunt Krasiński, Listy do A. Cieszkowskiego, t. I, Kraków-Warszawa 1912, s. 75. W latach późniejszych, zwłaszcza pod wpływem działalności Mickiewicza w okresie Wiosny Ludów, stosunek Krasińskiego do towiańczyków radykalnie się zmienił. 
Jako myśliciel religijny Zdziechowski był badaczem romantyzmu od strony filozoficznej. Począwszy od rozprawy Mesjaniści i Stowianofile, która była jego dysertacją doktorską, zastanawiał się nad istotą mesjanizmu i jego związkami z rosyjskim słowianofilstwem. W pracy Wizja Krasińskiego zauważył podobieństwo poglądów Mereżkowskiego, Bułgakowa, Bierdiajewa i Tołstoja do poglądów Cieszkowskiego przedstawionych w Prolegomenach... i Ojcze nasz. Z trzema myślicielami rosyjskimi Zdziechowski miał bezpośredni kontakt, o czym świadczy wieloletnia korespondencja z różnych lat. Nie wszystkich jednak spośród wymienionych myślicieli uważał za jednakowo sobie bliskich. W Wizji Krasińskiego Zdziechowski zarzuca Cieszkowskiemu nadmierny optymizm i „materialistyczny kierunek wyobraźni”, spokrewniający go z „odbywającym się za dni naszych w Rosji ruchem religijnym, którego był jakby zwiastunem" ". Zdziechowski aprobował natomiast idee Krasińskiego. W jego interpretacji autor Przedświtu, uważany zwykle za pisarza powtarzającego myśli Cieszkowskiego, okazał się być myślicielem religijnym, zasadniczo od Cieszkowskiego różnym. Akcentowanie tej różnicy było ważnym wkładem autora Wizji Krasińskiego do zrozumienia problematyki polskiego (a także rosyjskiego) mesjanizmu, jednocześnie zaś wiązało się to z osobistymi, filozoficzno-religijnymi poglądami profesora ${ }^{7}$.

W okresie poprzedzającym korespondencję, a także w czasie jej trwania, Zdziechowski pracował nad pracą Wizja Krasińskiego. Ze studiów nad literatura i filozofia polska, która ukazała się w Krakowie w roku 1912. Listy Cieszkowskiego syna datowane są na okres 1908-1914. Jednym ze źródeł, z jakiego z pewnością skorzystał Zdziechowski są listy Zygmunta Krasińskiego wydane dwa lata po śmierci poety w Paryżu ${ }^{8}$. Nie wiadomo jednak, czy Zdziechowski miał dostęp do listów Krasińskiego do Cieszkowskiego, które ukazały się

\footnotetext{
${ }^{6}$ Marian Zdziechowski, Wizja Krasińskiego. Ze studiów nad literatura i filozofia polska, Kraków 1912, s. 11.

Andrzej Walicki, Zdziechowski: Eschatologia a Millenaryzm, „Znak” 1992, nr 3, s. 59.

8 Zygmunt Krasiński, Wyjątki z listów Zygmunta Krasińskiego, Paryż 1861.
} 
w Krakowie w tym samym roku, co Wizja Krasińskiego, w wydaniu Kallenbacha. Nawet jeśli Zdziechowski miał do nich dostęp, z pewnością zabrakło mu listów filozofa do romantycznego twórcy, ponie-

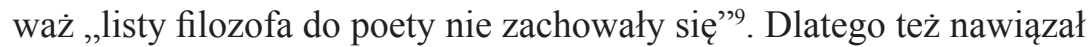
stosowną korespondencję z synem Augusta Cieszkowskiego, Augustem Adolfem Józefem (1861-1932).

Szanowny Panie Profesorze,

Stosownie do listu Pańskiego doczekałem do początku miesiąca z odpowiedzią, którą, choć nic nie mam korzystnego do doniesienia, spieszę przesłać, gdyż każdy list ciąży mi na sumieniu, jak dług.

Niekorzystną nazywam odpowiedź moją dla dwóch powodów: Panie nie mogę się podjąć całkowitego przejęcia nadzoru „Świata Słowiańskiego"11, a jeszcze mniej podpisywania, jako redaktor tego wydawnictwa. Nie żebym miał cokolwiek do zarzucenia wydawnictwu, którego choć nie znam, same nazwiska przez Szanownego Pana Profesora podane, dostatecznie polecają. Ale od czucia tego, podpisywania wydawnictwa własnym nazwiskiem niezmiernie daleko. Musiałbym istotnym zostać redaktorem, t.j.: każdy artykuł zanim wyjdzie poznać, $\mathrm{i}$ to $\mathrm{z}$ prawem cenzurowania go. Rzecz najzupełniej niemożliwa.

\footnotetext{
9 Zygmunt Krasiński, Listy do Augusta Cieszkowskiego, Edwarda Jaroszyńskiego, Bronisława Trentowskiego, t. I, oprac. i wstępem poprzedził Zbigniew Sudolski, Warszawa 1988, s. 8.

10 Wierzenica - wieś w powiecie poznańskim, pierwsze wzmianki w Słowniku geograficznym Królestwa Polskiego i innych krajów stowiańskich pochodzą z XII w., August Cieszkowski ojciec przeprowadził się tam na początku lat 40. XIX wieku z Podlasia. Ten mały majątek na terenie Wielkiego Księstwa Poznańskiego kupił Cieszkowskiemu (1814-1894) jego ojciec, by uniknąć szykan i podejrzeń ze strony władz rosyjskich

11 „Świat Słowiański” - miesięcznik wydawany w Krakowie w latach 1905-1914. Pismo poświęcone było słowianoznawstwu i przeglądowi spraw słowiańskich ze stanowiska polskiego. W latach 1905-1914 organ Klubu Słowiańskiego. Redaktorem naczelnym był Feliks Koneczny historyk, bliski współpracownik Zdziechowskiego. Głównymi ideami pisma wg F. Konecznego było ubezpieczenie i określenie własności narodowej Słowian.
} 
Druga niekorzystna wiadomość, którą podzielić się muszę jest, że udałem się do dwóch osób, z których jedna mi odmówiła, a druga nie odpowiedziała.

Czym mogę służę jak najchętniej, a to jest roczną subwencją 1000 [koron], jak długo ta suma okazałaby się potrzebną do utrzymania pisma przy obecnym kierownictwie.

Przychodzi mi jeszcze na myśl, czy nie warto by, aby się Panowie udali $\mathrm{w}$ tej kwestii do $\mathrm{hr}$ [abiego] Włodzimierza Skórzewskiego ${ }^{12}$ z Czerniejewa ${ }^{13}$, którego prof. Morawski ${ }^{14}$ zapewne zna.

Miło mi przy sposobności załączyć wyrazy najgłębszego poważania dla Pana Profesora.

Oddany stuga

A. Cieszkowski J

[2.]

25 lipca 1908

Szanowny Panie Profesorze,

Wstyd mnie doprawdy na list Pański tak późno odpowiadać.

Skoro wróciłem z Parmy, Pan Profesor wybrał się do Pragi, gdzie po prostu zazdrościć można pobytu pod wrażeniem jednogłośnych, tak dodatnich relacji. Z umysłu nikomu wszelkich superlatywów, których brak właśnie, czyli miara i powaga nastroju tak niesłychanie korzystne robiła wrażenie. Szczęśliwym byłbym, gdyby Pan Profesor, jako nie

12 Włodzimierz Skórzewski (1858-1913), hrabia, doktor prawa, członek pruskiej Izby Panów, syn ordynata Zygmunta Skórzewskiego, III ordynat na Czerniejewie-Radomicach z przyległościami, w zaborze pruskim.

13 Czarniejewo - miasto w Wielkopolsce, blisko Gniezna, od 1823 r. należało do rodziny Skórzewskich, herbu Drogosław. W 1885 r. Rajmund Skórzewski ustanowił z dóbr czerniejewskich ordynację, która przetrwała do 1939.

14 Kazimierz Morawski (1852-1925), ojciec nowożytnej polskiej filologii klasycznej, znawca literatury starożytnej, tłumacz Antygony, profesor i rektor Uniwersytetu Jagiellońskiego, prezes Polskiej Akademii Umiejętności, członek Poznańskiego Towarzystwa Przyjaciół Nauk, Towarzystwa Naukowego we Lwowie, kandydat na Prezydenta RP w grudniu 1922 r. Obok takich osób jak: K. Nitsch, J. Łoś, F. Papee, L. Gumplowicz, J. Baudoin de Courteney, A. Grzymała-Siedlecki, należał do Klubu Słowiańskiego (którego Zdziechowski był prezesem) aż do roku 1912. 
tylko uczony świadek, ale pars magna ${ }^{15}$, zechciał potwierdzić podniosłe wrażenie, którego tylko z dziennikarskich relacji zaczerpnąć mogłem. Nie taję, że przeszedł wszelkie moje oczekiwania, a poruszył najgłębsze serca uczucia, nie tylko patriotyczne, ale wprost humanitarne, bo jakimś różkiem ta struna u ciury, czy parobka ojczenaszowego przecież wyzierać musi. Ucieszył mnie na wstępie artykuł F. Konecznego ${ }^{16} \mathrm{~W}$,Świecie Słowiańskim”. Nie jestem politykiem; z punktu widzenia oportunizmu nie pozwalam sobie na żadne sądy, ale przedmiotowo rzecz biorąc, praca ta arcyniebanalna niejedno zawierała ,was mir aus der Stele gesprochenm war" ${ }^{\prime 17}$. Ale nade wszystko sam zjazd i nasza w nim rola, i zachowanie się bez jednej fałszywej nuty.

Choć bardzo późno odpowiadam na zapytanie Pana Profesora, że słuszne są jego przypuszczenia w sprawie udziału mego w wydawnictwie jubileuszowym na cześć Tołstoja ${ }^{18}$. Gdybym nawet przezwyciężył nieśmiałość, która przed hreczkosiejem ${ }^{19}$ zamyka podwoje produkcji literackiej, mógłbym tylko odezwać się o tej pracy Tołstoja, do której on sam żadnej nie przywiązuje wagi, jak nam to w Jasnej Polanie ${ }^{20}$ powiedział, tj.: o tej przedmowie do jego mów Zoli i Daudeta ${ }^{21}$ do

15 Et quorum pars magna fui - łac. w czym odgrywałem wielką rolę, w czym brałem wielki udział, etym. Wergiliusz, Eneida, 2, 6.

16 Feliks Karol Koneczny (1862-1949), redaktor wydawanego w Krakowie „Świata Słowiańskiego", polski historyk i historiozof, pracownik biblioteki Uniwersytetu Jagiellońskiego, Archiwum Akademii Umiejętności, członek krakowskiego Klubu Słowiańskiego. Publikował liczne artykuły w czasopismach: „Czas”, „Przegląd Polski”, „Przegląd Powszechny”. Od 1919 r. wykładowca na Uniwersytecie Stefana Batorego w Wilnie, po wojnie wrócił do Krakowa. Bliski współpracownik Zdziechowskiego z czasów organizowania krakowskiego życia kulturalno-patriotycznego. Za jego sprawą krakowski ruch prosłowiański został nazwany polskim słowianofilstwem.

17 Was mir aus der Stelle gesprochen war - niem. co było mówione do mnie na miejscu.

18 Korespondencja Zdziechowskiego i Tołstoja (1928-1910) obejmuje lata 1895-1896 oraz listy z lat 1899 i 1908.

19 hreczkosiej - ten, który sieje grykę, tu: ziemianin

20 Kolejne odniesienie do odwiedzin u Tołstoja i tematów, jakie były podejmowane w Jasnej Polanie.

21 Alphonse Daudet (1840-1897), pisarz, poeta i publicysta francuski, pochodził z Prowansji, którą opisywał w swojej twórczości. 
młodzieży francuskiej. Poza tym podziwiam poetę w nim, o wiele więcej, aniżeli myśliciela.

A propos studiów, o których Pan Profesor wspomina nad modernistycznym ruchem katolickim w Niemczech, przypominam sobie, że teraz niedawno miałem w ręku: Le Son des Cloches $^{22}$ świeżo zmarłego Gebharta. Ostatnia nowelka tego tomu Les dernières [aventures] $d u$ [divin] Ulysse ${ }^{23}$ uderzyła mnie jako dowód modernistycznego ruchu w judaizmie, względnie w prawosławiu. Jest to wspomnienie z podróży wschodniej Gebharta. Czy Pan Profesor to zna?

Łaczę wyrazy uszanowania

Stuga A. Cieszkowski J

[3.]

1 listopada 1908

Szanowny Panie Profesorze.

Przykro mi, że tak późno odpisuję na jego list, który mnie nadzwyczajnie interesował. Proszę mi wybaczyć, że tak późno przychodzą nań podziękowania. Kto istotnie ma dużo do pisania, może tylko podołać korespondencji, zaraz odpisując. Odpis odłożyłem, aby Pan Profesor mógł do Krakowa zdążyć, dziś widzę skutki tego pierwszego kroku.

Uderzyło mnie, co Pan Profesor pisze o Bobrińskim ${ }^{24}$. Wierzę temu najzupełniej. Zdanie, że on może najłatwiej mieć rządowych ludzi, rozumiem, co znaczy, prawie podzielam.

Byłem z nim dawniej blisko. Widywaliśmy się nieraz zwłaszcza z jego matką i braćmi za granicą. Jego nie widziałem od owego pobytu u nich w Bogorodzisku. Wiem, że się ożenił. Brata jego temu dwa lata

22 Émile Gebhart (1839-1908), francuski historyk kultury, pisarz; tu mowa o książce $A u$ son des Cloches: contes et légendes, Paris 1904.

23 Émile Gebhart, Les dernières aventures du divin Ulysse, 1902.

24 Włodzimierz Bobriński (1868-1921), hrabia, ziemianin z guberni tulskiej. Działacz ziemski w latach 1891-1893, później deputowany do II, III, IV Dumy Państwowej. Majątek rodzinny Bobrińskich znajdował się niedaleko od Jasnej Polany, którą Bobriński bardzo często odwiedzał. August Cieszkowski syn lato 1896 roku spędzał w Rosji gościnnie, zaproszony właśnie przez hrabiowską rodzinę Bobrińskich. To z Włodzimierzem Bobrińskim Cieszkowski syn odwiedził Tołstoja 28 sierpnia. 
w Warszawie widziałem. Samego Włodzimierza znałem, jako gorąca i szlachetną duszę, który wówczas religijnymi, a nie politycznymi kwestiami był zajęty. W tym kierunku ma nawet niemało oczytania. Kierował się na mnicha. Wprowadził mnie do kilkunastu klasztorów, których zwiedzanie jemu jedynie zawdzięczam, co uważam za nieodzowne, jeśli się chce trochę ducha Rosji poznać. Jest to szczerze i głęboko religijny człowiek, którego np. niektóre aksjomaty w Jasnej Polanie wygłaszane, do żywego bolały. Mówiliśmy o tych kwestiach bardzo otwarcie. Jak powiadam w tym kierunku i czytał i myślał, stąd był dla mnie wielce interesującym. Liberalne, postępowe, że tak powiem zapatrywania jego na przyszłość Cerkwi były wprost ujmujące. Nie był srogi połączeniu wschodniego z łacińskim Kościoła. Do tego stopnia nie, że w gruncie, zdaje mi się, był tego zwolennikiem bardzo szczerym. Ale nie miałem okazji poznać go pod względem aspiracji i zmysłu politycznego, gdyż prawie wyłącznie o religijnym temacie się mówiło. Sądzę, że bezwarunkowo szczery i szlachetny, może być trochę ,impulsywny” podług modnego dziś w niemieckiej prasie wyrażenia. Jako człowiek prawicy wielkiego rodu, skoligacony z wieloma wielkimi nazwiskami rosyjskimi, może być rządowi sympatyczniejszym od innych. Jakie ma zachowanie u dworu, albo u ludzi będących dziś u władzy, nie przesądzam. Wiem, że Cesarz zna go z czasów jego służby wojskowej. Są to wspomnienia z młodych lat, które jak nie bądź raczej korzystnie dlań usposabiać go mogą. To wszystko, co o nim powiedzieć mogę.

Jestem bardzo ciekaw, czy wstąpił do Krakowa, czy Pan Profesor się z nim widział, i jakie Pan odniósł wrażenie? Wierzę temu, co podają dzienniki, jakoby on chciał wnieść interpelację w sprawie szkół. Sądzę, że co najmniej można z obcowania z nim wyrozumieć niejedno, co naszym zachodnim zapatrywaniom nieraz się jako rebus przedstawia. Choćby tylko tyle, stosunki z nim mogą być nadaremne. Zwłaszcza, że to na wskroś szlachetna dusza.

Raz jeszcze przepraszając za opóźnienie odpowiedzi na tak miły i interesujący list Pana Profesora, proszę przyjąć wyrazy prawdziwego poważania.

Stuga-A. Cieszkowski J 
6 grudnia 1908

Szanowny Panie Profesorze,

Dopiero za powrotem z Rogalina ${ }^{25}$ odpisuję na list jego łaskawy. Przechodzimy tam z p. Edwardem ${ }^{26}$ Patria et Aristocratia moderne ${ }^{27}$, która tego roku wyszła powtórnie w Paryżu po francusku, a którą chciałbym koniecznie w tym roku jeszcze wydać w Poznaniu po polsku. Rok 1908, rok wywłaszczenia u nas, chciałbym aby był zapisany na okładce obydwóch dzieł mego Ojca, które pierwszy raz po polsku wychodzą: tj. Prolegomenów i Patria. Wydanie dwóch tych niebanalnych, że nie powiem proroczych książek mego Ojca w Poznaniu, stanowiłoby w moich oczach jedną z najobiektywniejszych odpowiedzi na zarzut niższości kulturalnej w szowinistycznym zaślepieniu, mający rzekomo usprawiedliwiać brutalność stanowionego przeciw nam prawa wywłaszczenia ${ }^{28}$. Wzorowe zachowanie się społeczeństwa tutejszego, po dziś dzień stanowi bezsprzecznie najlepszą odpowiedź. Najniegodniejszemu stróżowi wielkiej spuścizny po moim ojcu wybaczyć trzeba uczucie obowiązku poniekąd, aby ponadto $\mathrm{w}$ tak ciężkiej chwili wskrzesić w Poznaniu głos jego i uciskającym, jak uciskanym przypomnieć pozytywne, czyli dodatnie, budujące jego zasady.

25 Rogalin - wieś w Wielkopolsce, położona $20 \mathrm{~km}$ na południe od Poznania, nad rzeką Wartą. Pałac w Rogalinie był siedzibą wielkopolskiego rodu Raczyńskich, herbu Nałęcz.

${ }^{26}$ Edward Aleksander Raczyński (1847-1926), kolekcjoner dzieł sztuki, mecenas, twórca rogalińskiej galerii Raczyńskich, mąż córki Zygmunta Krasińskiego, Marii Beatrix Krasińskiej, później mąż Róży z Potockich Krasińskiej.

27 August Cieszkowski, De la pairie et l'aristocratie moderne [O izbie wyższej i arystokracji w naszych czasach] (Paris 1844), druga po Du credit et de la circulation [O kredycie i obiegu] (Paris 1839) książka Cieszkowskiego napisana po francusku uzasadniała konieczność zniesienia szlachty dziedzicznej i zastąpienia jej przez szlachtę zasługi, której reprezentacją byłaby zreformowana i znacznie wzmocniona izba wyższa parlamentu. Przez pewien czas Cieszkowski myślał nawet o realizowaniu tego programu w praktyce politycznej, książkę tę pisał początkowo w celu utorowania sobie drogi do parlamentu francuskiego.

28 Jeden ze sposobów walki z polskością w zaborze pruskim. W marcu 1908 r. sejm pruski uchwalił ustawę o przymusowym wywłaszczeniu polskich majątków. Rząd kanclerza Bernharda von Bülowa uderzał w ten sposób w ciągle niepokornych Polaków, przeciwstawiających się od dziesięcioleci pruskiej polityce germanizacyjnej. 
Równocześnie z tym listem piszę do Banku Królewskiego w Poznaniu, aby subsidium moje na „Świat Słowiański” ${ }^{29}$ wprost pod adresem Pana Profesora do Krakowa wysłał. Serdecznie cieszą mnie wiadomości o wzrastającym powodzeniu jego.

Nie dziwią mnie sprzeczności, które Pana Profesora uderzyły w najszlachetniejszej, spieszę dodać, duszy Bobrińskiego, jako polityka. W naszych czasach wszelka dusza ludzka skomplikowana, bo to czasy przełomu. Cóż dopiero wschodnia dusza. Całe szczęście, że z gruntu szlachetna.

Pozwalam sobie przesłać francuski egzemplarz Patria $^{30}$, skoro polski nakład jeszcze nie wyszedł.

Z wyrazami najwyższego poważania pozostaję Pana Profesora oddanym sługą

A Cieszkowski J

[5.]

15 lipca Sucha ${ }^{31}$

p[oczta]. Kałuszyn, gub[ernia]. warszawska

Szanowny Panie Profesorze,

Wyczytuję w „Słowie”32 telegram Pana Profesora wysłany do Sofii. Czy wolno mi najserdeczniej powinszować Panu Profesorowi? Zdumiałem nie nad tym, że taki telegram Pan Profesor wysłałeś, ale nad tym, że go tutejsze pismo powtórzyć mogło. Z wszystkich epitetów najzasłużeńszych, którymi Szanowny Pan nacechowałeś krótkowidztwo, ciemnotę, zaślepienie wprost obecnej polityki rosyjskiej w kwestii słowiańskiej, najbardziej ucieszyło mnie nazwanie jej antichretien$n e^{33}$. - Pomyślałem o naszym wspólnym znajomym, który jest chyba

\footnotetext{
29 Zob. przypis 11.

30 Zob. przypis 27.

31 Sucha - posiadłość Cieszkowskich na Podlasiu, tu urodził się August hr. Cieszkowski

32 „Słowo" - konserwatywny dziennik informacyjno-polityczny wydawany w latach 1882-1919 w Warszawie.

33 antichretienne - fr. antychrześcijański
} ojciec. 
wykładnikiem par excellence tego zaślepienia. Dla niego ten epitet jest potrzebny, aby przejrzał, - jeśli w ogóle jeszcze przejrzeć jest zdolnym. A nie mam prawa posądzać go o złą wiarę, choć pewno 15 lat już go nie widziałem. Gdyby po nim sądzić o drugich, po prostu truchleć próżno by nad skutkami podobnego zaślepienia, które zgubniejszymi być mogą od skutków nawet złej wiary. Ostatnia bowiem nie odbiera tak wielkiego uczucia nadziei. Podług Pisma Świętego narody Bóg „sanabiles creavit”34. Na operację katarakty narodowej do tej pory nic nie wynaleziono. Ale wszelki zakus w tej mierze jest dobry i chwalebny. I dlatego telegram Pana Profesora tak mnie serdecznie ucieszył.

Proszę przyjąć wyrazy serdecznego uszanowania

od Stugi Swego

A. Cieszkowski J

[6.]

Szanowny Panie Profesorze,

Sucha 22 lipca 1910.

Ein gutter Mensch in seinem dunklen Drange

Ist sich des rechten Weges wohl bewußt ${ }^{35}$.

Kaleczę Fausta, którego nie mam pod ręką, a stosuję to do tłumu krakowskiego, którego zachowanie $\mathrm{z}$ daleka podziwiam, na równi z Panem Profesorem, z Panem Konnim ${ }^{36}$, Milewskim ${ }^{37}$, z Francuzami i Rosjanami. A podziwiam nie platonicznie tylko, ale za naukę, którą mi dało. Nie jestem w ogóle zwolennikiem obchodów. Zarzucam im czczość, formalistykę, ceremonialność, próżnię. Otóż nauczył mnie

34 Sanabiles Deus fecit nationes - łac. Bóg uczynił narody uleczalnymi.

35 Niedokładny cytat z pamięci, fragment utworu w oryginale: „Ein guter Mensch in seinem dunklen Drange / ist sich des rechten Weges wohl bewusst" (cyt za: Johann Wolfgang Goethe, Faust, Berlin und Stuttgart 1887 [w. 85-86], s. 15), tłumaczenie: „Człek szlachetny prawdziwie / po omacku odnajdzie drogę swą szczęśliwie" (cyt. za: Johann Wolfgang Goethe, Faust, przeł. Feliks Konopka, Warszawa 1977, s. 18, w. 85-86.

36 Anatol Koni (1844-1927), prawnik rosyjski, przyjaciel Lwa Tołstoja.

37 Hipolit Milewski (1848-1932), ziemianin, działacz polityczny, członek rosyjskiej Rady Państwa. 
ów tłum, że uczucia tego, słusznego w zasadzie, uogólniać nie wolno. Zbiorowa dusza ludu, aby się wypowiedzieć samorodnie, musi się najpierw ,zebrać”. Fizycznie i moralnie. W tym tkwi konkretna wartość obchodów. Służyć mogą za podkład do owego ,zebrania się”, za „okazję", powiedziałby Malebranche ${ }^{38}$. Chodzi teraz o to, aby owa zbiorowa dusza była zdrową. Wtedy okazja może stać się błogosławioną, wprost dodatnią. Wypowiedzenie się zdrowej duszy narodu jest nie tylko cennym dla zagranicy, która nie może opierać się oczywistości. Obok egzaminu dojrzałości przed jej forum, o którym Pan Profesor wspominasz, niechaj mi wolno będzie widzieć korzyść dla ludu samego, czyli dla nas samych w takim fakcie. Bo nie ma czynu bez skutku, - w złem, czy w dobrem, a temu, co w pierwszym przypadku uczyniwszy zatwardziałością, odpowiada chyba w dobrem to, co nazywamy bierzmowaniem. Oby takt i dojrzałość polityczna okazana przez tłum krakowski przy obchodzie grunwaldzkim ${ }^{39}$ stała się dla nas bierzmowaniem na drodze legalnej, jasnej, rozumnej, bo moralnej pracy. Quvi felix faustum fortunatumque sit ${ }^{40}$.

$\mathrm{Z}$ wyrazem prawdziwego uszanowania Panu Profesorowi

Szczerze oddany

A Cieszkowski j

[7.]

Sucha 1 lipca 1913

P[oczta] Kałuszyn, gub[ernia]. warszawska

Szanowany Panie Profesorze,

38 Aluzja do okazjonalizmu - poglądu filozoficznego sformułowanego przez Nicolasa Malebranche'a (1638-1715). Według tego filozofa „plan działań” dla obu światów został stworzony przez Boga, co więcej, Bóg stale pilnuje, aby plany te były ściśle skoordynowane ze sobą.

39 Krakowskie obchody 500. rocznicy zwycięstwa nad Zakonem Krzyżackim stały się dla zniewolonych zaborami Polaków okazją do wielkiej manifestacji patriotycznej. Obchody trwały trzy dni (15-17 VII 1910). 17 lipca z Błoń na Wawel przeszedł pochód patriotyczny prowadzony przez banderię krakowską. Szli w nim członkowie delegacji z kraju i zagranicy, przedstawiciele towarzystw i komitetów, górale i chłopi w strojach ludowych, rzemieślnicy, profesorowie, duchowieństwo i młodzież.

40 Quod felix, faustum fortunatumque sit - łac. oby to było szczęśliwe, sprzyjające i pomyślne. 
Serdecznie dziękuję za list jego łaskawy, który tu odbieram oraz zaproszenie P[ana] Desjardins ${ }^{41}$, które Panu zawdzięczam. Niestety dziś przewidzieć nie mogę, czy we wrześniu będę wolnym i w tym sensie odpiszę P[anu] Desjardins. Wiedziałem już o zebraniach w Pontigny przez Adama Żółtowskiego ${ }^{42}$, który zeszłego roku w nich brał udział. Myśl o nich doskonała, służyć mogą nie tylko postępowi oraz rozpowszechnianiu postępu w kwestiach religijnych, społecznych i politycznych, ale bezsprzecznie i do jej pogłębienia. Program wszystkich dekad <est fort mourri et allechant $>^{43}$. Co piszę o sobie, nie jest więc banalną wymówką, jest istotną prawdą, nie sposób mi przewidzieć dziś, czy zdołam się uwolnić w porę. Skoro zaś tak jest, a przyjęcia zaproszenia odrzucić nie można, odpowiedź moja musi być odmowną.

Adama Żółtowskiego bardzo namawiałem do pojechania, gdy się do mnie w tej mierze odezwał. Niezmiernie cieszy mnie, że Pan Profesor jedzie, wielce byłbym ciekaw wykładu jego o towianizmie. Chociaż Ojcze nasz nic, a nic z towianizmem nie ma wspólnego, co podnieść z największą stanowczością nieraz za mój obowiązek uważałem, bynajmniej nie pozwalam sobie lekceważyć go, choćby ze względu na adeptów, których tak u nas, jak za granicą zjednać sobie zdołał. Wspominam Mickiewicza na to tylko, aby podać, iż nieraz słyszałem od Ojca mego wzmiankę niedozwalającą najmniejszej wątpliwości, że towianizm jemu przez całe życie pozostał czymś obcym. To żal wyraźny nad tym, że Mickiewicz mu uległ, to znów incydentalne podkreślenia, że Pan Zygmunt Krasiński nigdy na tę drogę nie zboczył, w najróżnorodniejszej formie pełno mam wspomnień w tej mierze. Dla mnie starczy to, co mi Ojciec mój na dwa dni przed śmiercią powiedział, o swym dziele, kiedy pierwszy raz w życiu do mnie o nim przemówił, aby nie

${ }_{41}$ Paul Desjardins (1859-1940), przedstawiciel neochrystianizmu francuskiego, publicysta i moralista, organizował cykl dekad związanych z ruchem modernistycznym w Kościele.

42 Adam Żółtowski (1881-1958), polski filozof, od 1939 roku na emigracji w Londynie. Autor dzieł O podstawach filozofii Hegla, Filozofia Kanta. Poprzedził wstępem pierwsze polskie wydanie Prolegomenów Augusta Cieszkowskiego.

${ }^{43}$ Est fort mouuri/mourir et allechant - fr. jest bardzo obfity i atrakcyjny (dosł. taki, na myśl o którym jaki leci ślinka). 
mieć żadnej wątpliwości, co do jego genezy. Podałem to w przedmowie do bardzo niezadowalającego tłumaczenia mojego na język polski Prolegomenów mego Ojca, a Adam Żółtowski genezę Ojcze nasz rzeczowo wyjaśnił w swej doskonałej: Philosophie der That.

W każdym razie proszę wierzyć, że serdecznie wdzięczny jestem Panu Profesorowi za pamięć o mnie, i z niekłamanym żalem odmowną odpowiedź przesyłam Panu Desjardins na zaproszenie do Pontigny, które Panu serdecznie zawdzięczam.

Proszę przyjąć wyrazy najgłębszego uszanowania, z którym pozostaję

\section{oddanym stuga Pana Profesora \\ August Cieszkowski J}

[8.]

Wierzenica, d[nia]. 18 sierpnia 1913.

Wielce Szanowny Panie Profesorze,

Odbieram list jego tutaj, odesłany z Suchej. Stąd także opóźnienie w odpowiedzi, za które przepraszam. Wyjechać musiałem z Suchej niespodziewanie, tu zaś nabawiłem się influenzy, która powrót mój opóźniła; wracam tam niebawem.

Serdecznie żałuję, że odmówić sobie muszę wycieczki do Pontigny; program zebrań jest bardzo interesujący. Na wszystkich dekadach chciałoby się być, a nie jak P[an] Desjardins najłaskawiej pisze, na pierwszej tylko i na czwartej. Ale nie mówiąc już o tym, czy jak zdołałbym Ojcze nasz w streszczeniu przedstawić rzeczowo, zachodzi w moich oczach inne ważniejsze pytanie: czy wolno już o nim mówić przed obcym audytorium, które nie może dotychczas dzieła samego poznać. Iurare in verba magistri ${ }^{44}$ to piękna zasada, gdy się jest magistrem c:a.d.quaud le pavillou course lo mnochau dise $e^{45}$. Ale nieudany

44 Iurare in verba magistri - łac. przysięga na słowa nauczyciela, mistrza; etym. Listy Horacego $(1,1,14)$.

${ }_{45}$ C: a.d.quaud le pavillou course lo mnochau dise - fr. flaga powiewa nad towarem ukrytym pod dachem. 
hreczkosiej ${ }^{46}$ nie mógłby odpowiedzieć zbyt łaskawemu wezwaniu do Pontigny, zanim towaru swego dostępnym nie uczyni, tj. przynajmniej istniejących po dziś dzień tomów nieprzetłumaczonych. Wydałem tom I z Drogami Ducha, po francusku, mam gotowy tom III, ale nie wydrukowałem go jeszcze II i IV carent vacat ${ }^{47}$. $<\ldots>^{48}$. - Co innego Żółtowski; ma za sobą doskonałą książkę swoją o tym temacie: Die Philosophie der That. Może i powinien dać jej krótkie streszczenie. To rozumiem nie tylko, ale bardzo pochwalam, popierałem, mówiłem, popierać i mówić będę. Kogo jego wywody zainteresują, może je odnaleźć w jego książce. Otóż na stałym gruncie, nie w obłokach operacja - na wiarę. Mam nadzieję, że pojedzie Adaś Żółtowski; jeszcze przed wyjazdem moim do Królestwa namówiłem go do tego, gdy napisał do mnie $w$ tej mierze. Ale gdyby nie pojechał? Jeszcze nie zdołałbym dzielić zapatrywania Pana Profesora, że z samym Towiańskim jechać nie warto. Nie mówiąc już, że kto Mickiewicza i tylu obok niego pomniejszych, ale wybitnych ludzi zawojował, nie mógł być przeciętną postacią u nas i dla nas. Myślę o zagranicy, gdzie wpływ jego dostatecznie się zakorzenił, aby po dziś dzień ciekawość i zainteresowanie budzić w pewnych kołach. Wykład o nim w Pontigny wydaje mi się bardzo na czasie i bardzo wskazanym, i dla samego tego wykładu z duszy i z serca pojechać tam pragnąłbym. Inna rzecz, czy połączenie z nim dzieła mego Ojca byłoby historycznie ścisłym, a obustronnie odpowiednim. Ani Ojciec mój, ani Pan Zygmunt Krasiński nigdy jego wpływowi nie ulegali. Nie cały więc mesjanizm polski, o ile w filozofii naszej się odzywa, z tego źródła wyrasta. Łącząc Ojcze nasz lub Psalmy P[ana] Zygmunta z wykładem o Towiańskim, albo zaznaczyłoby się to, albo przemilczało. W pierwszym przypadku obce audytorium mogłoby w tym krytykę towianizmu upatrywać, w drugim do błędnych wniosków czuć się spowodowanym. Dlatego w tej mierze nie dzielę zapatrywania Pana Profesora; wykład o Towiańskim jest

\footnotetext{
46 Zob. przypis 19.

47 carent vacat - fr. w przygotowaniu

48 Zdanie nieczytelne.
} 
najzupełniej wskazanym i wystarczającym dla Pontigny, nawet bez łączenia $\mathrm{z}$ tym filozofii mego Ojca i P[ana] Zygmunta, które obce są towianizmowi. Ale to nie znaczy, żebym nie namawiał Ad[ama] Żółtowskiego do Pontigny, owszem, jak wprzód tak i teraz bardzo namawiam.

Proszę przyjąć wyrazy prawdziwego uszanowania, z którym pozostaję

oddanym stuga Pana Profesora

A Cieszkowski

$*$

Znaki edytorskie i skróty używane w transkrypcji i komentarzach:

$<>-$ nawiasy kątowe w tekście utworu sygnalizują wyrazy trudne do odczytania, przypuszczalne formy, domysły wydawcy;

[ ] - nawiasami kwadratowymi oznaczono rozwiązania skrótów oraz uzupełnienia o charakterze redakcyjnym (np. $P . \rightarrow P[a n a] ; A d . \rightarrow$ Ad[ama]).

Opis źródeł

Listy wydano na podstawie autografów pisanych na arkuszach A5, które zachowały się w sekcji rękopisów Biblioteki Uniwersytetu Wileńskiego, w zbiorach dotyczących Mariana Zdziechowskiego, sygn. F-352. Na ich podstawie dokonano transkrypcji. Listy te nigdy przedtem nie ukazały się w druku. Głównym powodem ich wyboru była potrzeba przybliżenia kontekstu dotyczącego zainteresowań Zdziechowskiego epoką romantyzmu.

Zasady transkrypcji

Interpunkcja

Zastosowano dzisiejszy system interpunkcyjny. Zachowano ciekawsze próby zapisu interpunkcji (w przypadku wyszukanej składni lub wtrąceń autora). 
Wielkie i małe litery oraz znaki diakrytyczne

Ujednolicono zapis wielkich i małych liter. Zachowano zapis wielką literą zwrotów grzecznościowych, wyrażający respekt wyraz „ojciec" pisany z wielkiej litery, np. mego Ojca, oraz wyrazy Cerkiew i Cesarz.

Zmieniono zapis wielkiej litery na małą w przypadku niektórych rzeczowników pojawiających się w tekście, np.:

Towianizm $\rightarrow$ towianizm

Książka $\rightarrow$ książka (w listach Cieszkowski zawsze używał wielkiej litery pisząc o książce Adama Żółtowskiego Die Philosophie der That, co mogło być naleciałością z języka niemieckiego).

Zmieniono również zapis zaimka względnego:

Który $\rightarrow$ który

Poza tym:

Krótkowidztwo $\rightarrow$ krótkowidztwo

Kwestyi $\rightarrow$ kwestii

Pisownia ta wynikała z mianiery autora związanej z pisaniem małej litery $k$ tak, jak wielkiej.

Pisownia łączna i rozdzielna

Zmodernizowano pisownię łączną i rozdzielną. Wyrazy zapisano zgodnie z dzisiejszą normą:

nie mało $\rightarrow$ niemało

nietylko $\rightarrow$ nie tylko

nie dozwalająca $\rightarrow$ niedozwalająca

\section{Liczebniki}

Ujednolicono zapis liczebników porządkowych. Zmodernizowano także liczebnik główny nieokreślony:

wiela $\rightarrow$ wiele

axyomata $\rightarrow$ aksjomaty 
Nazwiska

Nazwisko Tolstoia zmodernizowano do dzisiejszej formy. Prawdopodobnie autor listów sugerował się przy zapisie rosyjską wymową nazwiska pisarza lub artykulacją głoski $l$-stąd różnica. Zmodernizowano również sposób zapisu nazwiska Cieszkowskij, którym autor podpisuje wszystkie listy z wyjątkiem ostatniego. Choć forma podpisu w autografie wygląda na zapis w stylu rosyjskim, jest ona raczej kompilacją nazwiska z inicjałem trzeciego imienia (Józef) lub pierwszą literą słowa ,junior":

Tolstoia $\rightarrow$ Totstoja

Cieszkowskij $\rightarrow$ Cieszkowski J

Głoski $i, y$

Głoski $i, y$ zapisano zgodnie z dzisiejszymi regułami:

$$
\begin{aligned}
& \text { Iego } \rightarrow \text { Jego } \\
& \text { Tolstoia } \rightarrow \text { Totstoja } \\
& \text { patryotyczne } \rightarrow \text { patriotyczne } \\
& \text { mesyanizm } \rightarrow \text { mesjanizm } \\
& \text { kwestyach } \rightarrow \text { kwestiach }
\end{aligned}
$$

W wyrazach obcego pochodzenia zmodernizowano wahania rękopisu w zakresie transkrypcji grup $-i j,-y j$ do $-j a$ :

$$
\begin{aligned}
& \text { interpelacye } \rightarrow \text { interpelacje } \\
& \text { operacye } \rightarrow \text { operację } \\
& \text { okazye } \rightarrow \text { okazje } \\
& \text { okazyi } \rightarrow \text { okazji } \\
& \text { relacyi } \rightarrow \text { relacji } \\
& \text { produkcyi } \rightarrow \text { produkcji } \\
& \text { aspiracyi } \rightarrow \text { aspiracji }
\end{aligned}
$$

Zaimki

Zachowano $\mathrm{w}$ tekście zapis form zaimkowych $\mathrm{z}-n \dot{n}$ : 
nań

dlań

Fleksja

Zmodernizowano końcówki narzędnika przymiotników i zaimków do dzisiejszej normy, np.:

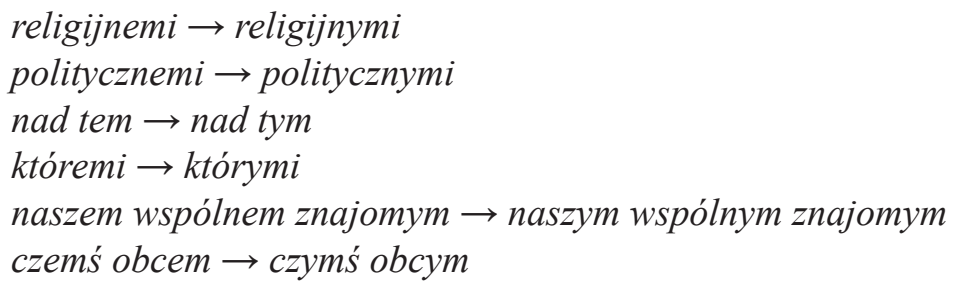

Pozostawiono niezmienione dwa słowa w liście drugim: $w$ dobrem, $w$ złem $\mathrm{w}$ celu podkreślenia swoistości języka nadawcy listów oraz jego tonu.

Składnia

Pozostawiono składnię zdań z orzeczeniem imiennym i orzecznikiem przymiotnikowym nadrzędnym.

Zapis daty

Pozostawiono jak w autografie, rozwijając jedynie skróty.

Monika Marlęga

\section{August Cieszkowski junior's letters to Marian Zdziechowski from the years 1907-1913}

Marian Zdziechowski has long been a big absentee in Polish humanities, even though he played a significant role in the intellectual life of the half of the century rich in cultural and political turns. His sensitivity and sensitiveness to the novelties of the intellectual trends of the 
epoch let him diagnose the contemporary human condition fairly quickly. They also allowed for him to accurately point to the necessities of the moment, both within the historical and religious fields. Zdziechowski had a particular ability to openly look at man, religion, history and philosophy, hence the possibility to acquaint oneself even with just a small part of his correspondence may prove extremely valuable.

Cieszkowski junior's letters to Marian Zdziechowski from 1907-1913 , that are presented here, are the source of information on Zdziechowski's interest in Polish Romanticism and the bases and inspirations of Polish philosophy of the period. These letters bring the addressee closer to the reader, which is characteristic of correspondence in general. The reading of these letters makes us direct witnesses to the views expressed in them and discussions relevant to the letters' recipient. The issues addressed in the letters concern mostly the origins of Polish messianism, Towianism and its possible influence on Zygmunt Krasiński and the philosophy of August Cieszkowski, the question of the Slavic Idea and the way of perceiving Russia. 